\title{
Evaluation of the systemic antiinflammatory effects of levosimendan in an experimental blunt thoracic trauma model
}

\author{
Gökay Ateş, M.D., ${ }^{1}$ Ferda Yaman, M.D., ${ }^{1}$ Bülent Bakar, M.D., ${ }^{2}$ Üçler Kısa, M.D., ${ }^{3}$ \\ Pınar Atasoy, M.D., ${ }^{4}$ Ünase Büyükkoçak, M.D. ${ }^{1}$
}

\begin{abstract}
${ }^{1}$ Department of Anesthesiology and Reanimation, Kırıkkale University Faculty of Medicine, Kırıkkale-Turkey
${ }^{2}$ Department of Neurosurgery, Kırıkkale University Faculty of Medicine, Kırıkkale-Turkey

${ }^{3}$ Department of Biochemistry, Kırıkkale University Faculty of Medicine, Kırıkkale-Turkey

${ }^{4}$ Department of Pathology, Kırıkkale University Faculty of Medicine, Kırıkkale-Turkey
\end{abstract}

\begin{abstract}
BACKGROUND: Blunt thoracic injury often leads to pulmonary contusion and the development of acute respiratory distress syndrome, which carries a high risk of morbidity and mortality, originating from the local and systemic inflammatory states. This study aimed to investigate the local and systemic antiinflammatory effects of levosimendan in rat models of blunt chest trauma.
\end{abstract}

METHODS: A total of 32 Wistar albino rats were randomly assigned to one of the following four groups: control, sham, low-dose levosimendan (LDL) $(5 \mu \mathrm{g} / \mathrm{kg}$ loading dose for $10 \mathrm{~min}$ and $0.05 \mu \mathrm{g} / \mathrm{kg} / \mathrm{min}$ intravenous infusion), and high-dose levosimendan (HDL) (I0 $\mu \mathrm{g} / \mathrm{kg}$ loading dose for $10 \mathrm{~min}$ and $0.1 \mu \mathrm{g} / \mathrm{kg} / \mathrm{min}$ intravenous infusion). Blunt chest trauma was induced, and after $6 \mathrm{~h}$, the contused pulmonary tissues were histopathologically and immunohistopathologically evaluated, serum TNF- $\alpha$, IL-I $\beta$, IL-6, and NO levels were biochemically evaluated.

RESULTS: The mean arterial pressure was low throughout the experiment in the LDL and HDL groups, with no statistically difference between the groups. Levosimendan reduced the alveolar congestion and hemorrhage, which developed after inducing trauma. Neutrophil infiltration to the damaged pulmonary tissue was also reduced in both the LDL and HDL groups. In rats in which pulmonary contusion (PC) was observed, increased activation of nuclear factor kappa B was observed in the pulmonary tissue, and levosimendan did not reduce this activation. Both high and low doses of levosimendan reduced serum IL-I $\beta$ levels, and high doses of levosimendan reduced IL- 6 and NO levels. TNF- $\alpha$ levels were not reduced.

CONCLUSION: In conclusion, the results showed that in a rat model of PC, the experimental agent levosimendan could reduce neutrophil cell infiltration to damaged pulmonary tissues and the systemic expressions of some cytokines (IL-I $\beta$, IL-6, and NO), thereby partially reducing and/or correcting pulmonary damage. Systemic inflammatory response that occurs after trauma could also be reduced.

Keywords: Blunt chest trauma, levosimendan; inflammation; lung contusion; nuclear factor- $\kappa \mathrm{B}$.

\section{INTRODUCTION}

The pulmonary contusion (PC) table associated with blunt chest trauma is a clinical table observed with alveolar conges-

Address for correspondence: Ferda Yaman, M.D.

Dr. Ahmet Taner Kışlalı Caddesi, Deniz Sitesi, 9. Blok, No: 5, Kat: 3, Çayyolu, Ankara, Turkey

Tel: +90 318 - 444407 I E-mail: ferdayaman@gmail.com

Submitted: 14.03 .2016

Accepted: 07.11 .2016

Ulus Travma Acil Cerrahi Derg

2017;23(5):368-376

doi: $10.5505 /$ tjtes.2016.26786

Copyright 2017

TJTES tion, hemorrhage, destruction of the alveolar structure integrity, edema, leukocyte infiltration, and hypoxemia with severe hypercarbia, and the course may vary with an increased respiratory burden. ${ }^{[1,2]}$ In 2009, Hoth et al. reported that PC that develops because of blunt thoracic trauma stimulates the systemic natural immune response and causes an increase in proinflammatory cytokines. ${ }^{[3]}$ The activation of the immune system, which occurs after massive injury, and the early inflammatory immune response, which is developed, is defined as systemic inflammatory response syndrome. ${ }^{[4]}$ It has been shown in the literature that nuclear factor kappa $B(N F-\kappa B)$ has a significant role in controlling the expression of mediators, including inflammation-related factors, TNF- $\alpha$, IL-I $\beta$, and adhesion molecules, which emerge in association with acute pulmonary injury and acute respiratory distress syn- 
drome (ARDS). ${ }^{[5-7]}$ Blunt chest trauma and PC, which develops with all of these features, have a high risk of morbidity and mortality. ${ }^{[8,9]}$

Levosimendan increases the affinity of $\mathrm{Ca} 2+$ to troponin $\mathrm{C}$ $(\mathrm{TnC})$ and is a pyridazinone-dinitrile-derived class III Ca2+sensitizing agent. By providing a dose-dependent connection of $\mathrm{Ca} 2+$ to the $\mathrm{TnC} \mathrm{N}$-terminal region, troponin activation is provided by inhibiting troponin I ( Tnl) and $\mathrm{TnC}-\mathrm{Ca} 2+$ stabilization. ${ }^{[10]}$ At the same time, levosimendan is a new drug that increases cardiac output with positive inotropic and vasodilation properties, without increasing the need for myocardial oxygen consumption. It has also been shown in the literature that besides these properties, oxidative pulmonary damage associated with reperfusion and inflammatory cytokines (ILI, IL-6, TNF- $\alpha$, etc.) in ventilator-related pulmonary damage and sepsis experimental models are reduced, and cellular level inflammation and proinflammatory responses are suppressed. ${ }^{[1-14]}$

This study outlines the therapeutic properties and effects of levosimendan on the potential systemic antiinflammatory response in an experimental rat model of unilateral PC.

\section{MATERIALS AND METHODS}

\section{Material}

This experimental study was performed according to the guidelines for the use of laboratory animal subjects in research set by the Ethics Committee of Kırıkkale University (Date: 02.13.20I4; Number: 14/03-33).

In this experimental study, the experimental agent levosimendan (Simdax, Orion Corporation, Finland) was intravenously infused at a low dose $(5 \mu \mathrm{g} / \mathrm{kg}$ loading dose for $10 \mathrm{~min}$, followed by $0.05 \mu \mathrm{g} / \mathrm{kg} / \mathrm{min}$ maintenance dose) and a high dose ( $10 \mu \mathrm{g} / \mathrm{kg}$ loading dose for $10 \mathrm{~min}$ and $0.1 \mu \mathrm{g} / \mathrm{kg} / \mathrm{min}$ maintenance dose). The oral LD50 dose of levosimendan is defined as $980 \mathrm{mg} / \mathrm{kg}$ in rats.

A total of 32 male Wistar albino rats, each weighing 300-350 $\mathrm{g}$, were used in the study. The number of rats to be included in the groups was determined based on similar studies in the literature, and the number of rats to be used was confirmed by power analysis. The rats were randomly allocated to one of the following four groups.

- Control group ( $\mathrm{n}=8$; sedation anesthesia was administered but no contusion was induced)

- Sham group ( $\mathrm{n}=8$; after inducing contusion, $1.5 \mathrm{ml} / 100 \mathrm{~g} / \mathrm{h}$ of physiological saline was intravenously administered)

- Low-dose levosimendan (LDL) group (after inducing contusion, levosimendan was administered as a $5-\mu g / k g$ loading dose for $10 \mathrm{mins}$, followed by $0.05 \mu \mathrm{g} / \mathrm{kg} / \mathrm{min}$ as an intravenous infusion)
- High-dose levosimendan (HDL) group (after inducing contusion, levosimendan was administered as a $10-\mu g / \mathrm{kg}$ loading dose for 10 mins, followed by $0.1 \mu \mathrm{g} / \mathrm{kg} / \mathrm{min}$ as an intravenous infusion)

For sedation anesthesia, $40 \mathrm{mg} / \mathrm{kg}$ ketamine $\mathrm{HCl}$ (Ketalar $®$ $5 \%$; Pfizer Inc., USA) and $5 \mathrm{mg} / \mathrm{kg}$ xylazine $\mathrm{HCl}$ (Rompun® $2 \%$; Bayer HealthCare AG, Germany) were intraperitoneally administered.

\section{Method}

With all rats under sedation anesthesia, a vascular route was opened from the tail veins using a 24G yellow intracatheter. Invasive monitorization was performed for $6 \mathrm{~h}$ for each rat fixed on a fixation plate, the left femoral artery was explored, and a catheter was placed in the artery under microscope guidance. After these preparatory procedures, unilateral pulmonary injury was induced in the right hemithorax of each rat via a modified form of the trauma mechanism developed by Raghavendran et al. (with the method of a $0.5 \mathrm{~kg}$ cylindrical body falling from a height of $0.4 \mathrm{~m}$; energy created, $E=I .96$ J) (Fig. I). ${ }^{[15]}$ To reduce cardiac injury to a minimum and have a minimum effect on hemodynamic instability, the contusion was unilaterally induced to the right lung.

Then, keeping the control group aside, the rats of the sham group were administered $1.5 \mathrm{ml} / 100 \mathrm{~g} / \mathrm{h}$ of physiological saline infusion; those of the LDL group were administered levosimendan as a $5-\mu g / \mathrm{kg}$ loading dose for $10 \mathrm{~min}$, followed by $0.05 \mu \mathrm{g} / \mathrm{kg} / \mathrm{min}$ intravenous infusion; and those of the HDL group were administered levosimendan as a $10-\mu \mathrm{g} / \mathrm{kg}$ loading dose for $10 \mathrm{~min}$, followed by $0.1 \mu \mathrm{g} / \mathrm{kg} / \mathrm{min}$ intravenous infusion. Throughout the experiment, systolic and diastolic blood pressures, mean arterial pressures, and heart rates (HRs) of all rats were monitored and recorded (Fig. I). The rats were kept warm under a blanket throughout the experiment, and oxygen support was provided. After $6 \mathrm{~h}$, median sternotomy was performed for all the rats under anesthesia, and euthanasia was performed by draining all the blood from the body via the cardiac route. The right lung was completely excised
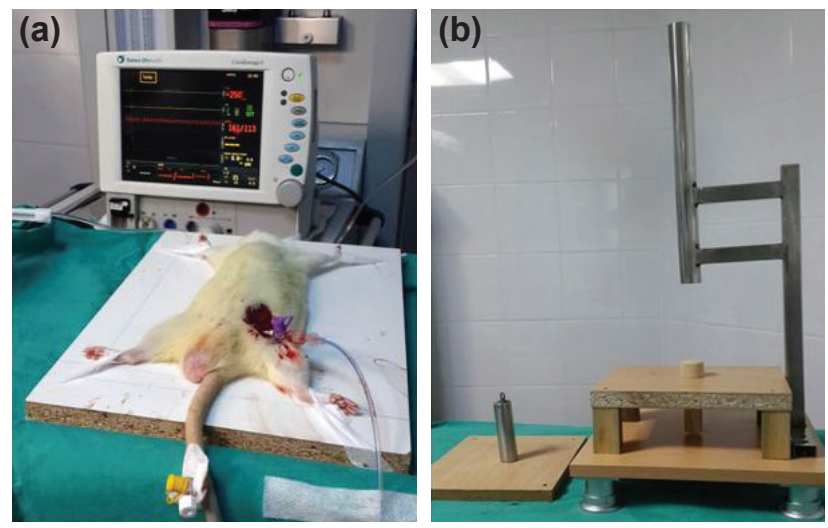

Figure 1. Arterial pressure monitorization (a) and blunt thorax trauma experiment mechanism (b). 
from each rat. The tissues and blood samples obtained were used for pathological, Immunohistochemical, and biochemical analysis.

\section{Histopathological Evaluation}

After fixation of the pulmonary tissues obtained in 10\% formaldehyde solution, the samples were embedded in paraffin blocks, and then, $5-\mu \mathrm{m}$-thick slices were cut and stained with hematoxylin and eosin. The preparates obtained were evaluated using a light microscope (Leica DM 2500) by an experienced pathologist who was blinded to the study groups. The areas of lung contusion were classified according to the presence of neutrophil infiltration, alveolar hemorrhage, alveolar congestion, and hyaline membrane formation, as described below (Fig. 2).

- Grade 0: minimal damage

- Grade I: little damage

- Grade 2: moderate damage

- Grade 3: severe damage
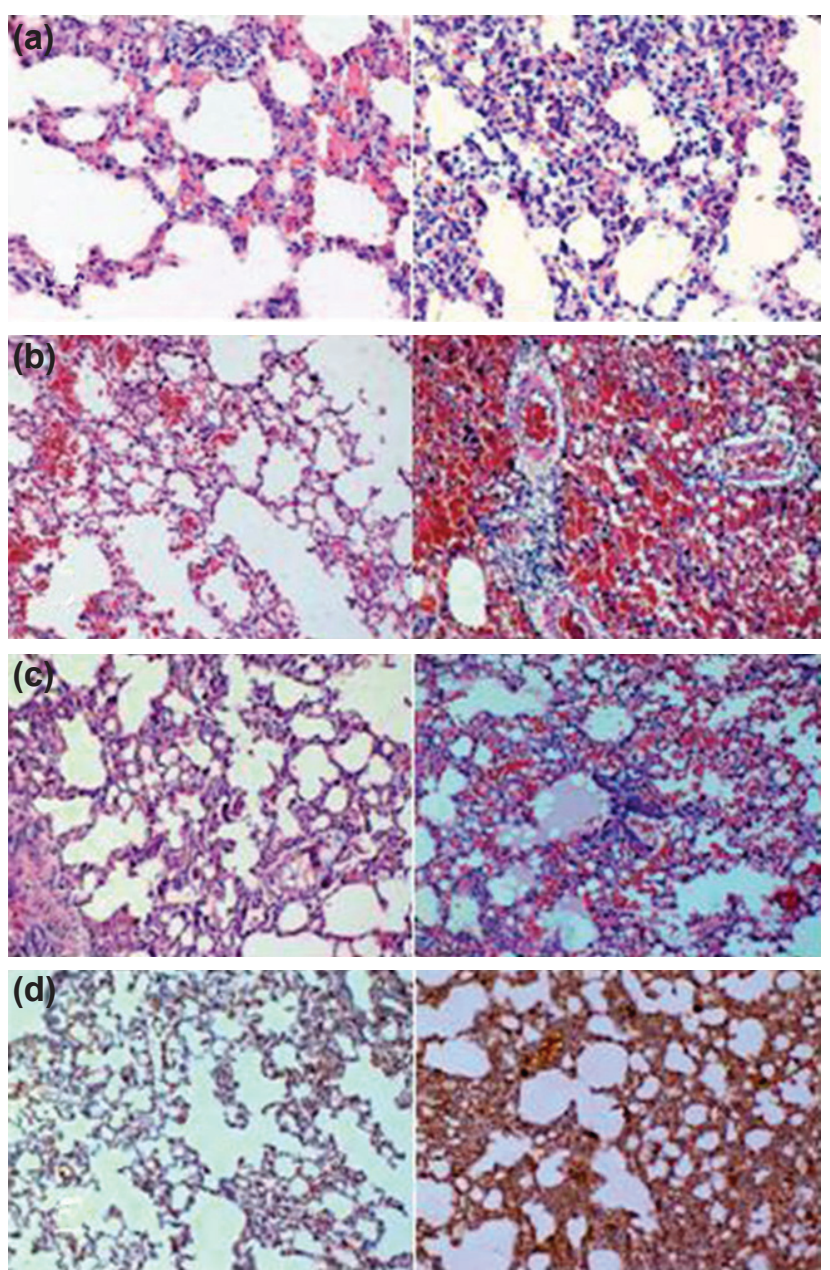

Figure 2. Areas of neutrophil infiltration, alveolar hemorrhage, and alveolar congestion in the alveolar wall showing Grade 1 on the left and grade 3 on the right $(\mathrm{HE} ; \times 100)(\mathrm{a}-\mathrm{c})$; stained areas in the lung showing grade 1 NF-KB and grade 3 on the right $(\times 200)(d)$.

\section{Immunohistochemical Evaluation}

Pulmonary tissues were washed with $4 \%$ paraformaldehyde, and after dehydration, they were embedded in paraffin blocks. Using standard histological techniques, 5- $\mu \mathrm{m}$-thick slices were cut. All slices were heated at $60^{\circ} \mathrm{C}$ for $60 \mathrm{~min}$ in an oven and then deparaffinized. After the endogenous peroxidase reaction, blocking was performed using 3\% $\mathrm{H} 2 \mathrm{O} 2$ for $30 \mathrm{~min}$. The samples were then washed thrice using a phosphate-buffered solution and incubated overnight in a solution of anti-rat NF- $\kappa$ B polyclonal antibody (Santa Cruz, CA, USA), which was diluted at room temperature $1 / 100$ with primary rabbit. Biotin peroxide and diaminobenzidine brown-yellow colors were used in the development of the findings. The results obtained were evaluated by an experienced pathologist who was blinded to the study groups, and the NF- $\kappa B$ values in each slice were classified under a microscope (BenchMark GX, Ventana Medical Systems Inc.) using the histopathological classification method stated above.

\section{Biochemical Evaluation}

The blood samples obtained from the rats were centrifuged at $3000 \mathrm{rpm}$ for 10 mins; the serum samples were collected and immediately frozen in dry air at $-80^{\circ} \mathrm{C}$ and stored until analysis. All serum samples were evaluated with respect to ILI $\beta$, IL-6, TNF- $\alpha$, and NO levels by an experienced biochemist who was blinded to the study groups. The Platinum ELISA kit method was used for all serum samples (Affymetrix, eBioscience Inc., USA), and the results were calculated as $\mathrm{pg} / \mathrm{ml}$ for IL-I $\beta$ and IL-6, ng/L for TNF- $\alpha$, and as $\mu \mathrm{mol} / \mathrm{L}$ for NO.

\section{Statistical Analysis}

All statistical analyses were conducted using the SPSS 22.0 statistical software (SPSS Inc., Chicago IL, USA).

The histopathological grades and TNF- $\alpha$ levels that were not normally distributed and the variation was not homogenous between all groups were statistically analyzed using Kruskal-Wallis test. To determine the statistical differences between the groups (post hoc evaluation), Mann-Whitney $U$ test (with Bonferroni correction) was performed for all grade results. $p$ values of $<0.0083$ were considered to be significant.

The values of the hemodynamic parameters and IL-I $\beta$, IL6 , and NO levels were normally distributed, and the variations were homogenous among the groups. Therefore, oneway analysis of variance (ANOVA) was performed for all the values. To determine the statistical differences between the groups, post hoc evaluation (one-way ANOVA-Tukey multiple comparisons test) was performed. $p$ values of $<0.05$ were considered to be significant.

\section{RESULTS}

\section{Hemodynamic Measurement Evaluation}

Throughout the $6 \mathrm{~h}$ of the experiment, the systolic and dia- 
stolic blood pressures, mean arterial pressures, and HRs of all the rats were monitored and recorded. After inducing the trauma, bradycardia and hypotension developed in all the rats. At 20 min after the trauma, HR values were significantly higher in the LDL and HDL groups than in the sham group $(p=0.031)$. The mean arterial pressure values tended to be high in the sham group after $30 \mathrm{~min}$, and after $6 \mathrm{~h}$, the val- ues reached the baseline values. In the LDL and HDL groups, the mean arterial pressure values were observed to be low throughout the experiment, with no statistically significant difference observed between the groups.

\section{Histopathological Evaluation}

Statistical analysis of the results of the histopathological ex-

Table I. Descriptive table of the histopathological grades

\begin{tabular}{|c|c|c|c|c|c|}
\hline Group & Variable & Minimum & Maximum & Mean/Median(") & Standard deviation \\
\hline \multirow[t]{9}{*}{ Control } & Alveolar congestion & 0 & 1 & $0^{*}$ & 0.35 \\
\hline & Alveolar hemorrhage & 0 & 1 & $0^{*}$ & 0.35 \\
\hline & Hyalen membrane & 0 & 0 & $0^{*}$ & 0.00 \\
\hline & Neutrophil infiltration & 0 & 1 & $0^{*}$ & 0.35 \\
\hline & NF-кB & 0 & 1 & $0^{*}$ & 0.35 \\
\hline & TNF- $\alpha$ & 43.85 & 52.88 & $46.7 I^{*}$ & 4.12 \\
\hline & IL-I $\beta$ & 285.70 & 548.20 & 408.03 & 102.20 \\
\hline & IL-6 & 19.19 & 45.66 & 2941 & 9.97 \\
\hline & NO & 6.13 & II.87 & 8.71 & 2.23 \\
\hline \multirow[t]{9}{*}{ SHAM } & Alveolar congestion & 1 & 2 & $I^{*}$ & 0.52 \\
\hline & Alveolar hemorrhage & 1 & 3 & $\mathrm{I}^{*}$ & 0.74 \\
\hline & Hyalen membrane & 0 & 0 & $0^{*}$ & 0.00 \\
\hline & Neutrophil infiltration & 1 & 2 & $1^{*}$ & 0.35 \\
\hline & NF-кB & 1 & 3 & $2^{*}$ & 0.84 \\
\hline & TNF- $\alpha$ & 45.67 & 119.83 & $76.07^{*}$ & 23.89 \\
\hline & IL-I $\beta$ & 801.70 & 2161.60 & $14 \mid 2.60$ & 480.41 \\
\hline & IL-6 & 22.64 & 59.47 & 36.74 & 12.93 \\
\hline & NO & 7.34 & 14.19 & 10.08 & 2.24 \\
\hline \multirow[t]{9}{*}{ LDL } & Alveolar congestion & 1 & 3 & $1.5^{*}$ & 0.74 \\
\hline & Alveolar hemorrhage & 0 & 3 & $1^{*}$ & 0.92 \\
\hline & Hyalen membrane & 0 & 1 & $0^{*}$ & 0.35 \\
\hline & Neutrophil infiltration & 0 & 1 & $0^{*}$ & 0.52 \\
\hline & NF-кB & 1 & 3 & $1.5^{*}$ & 0.74 \\
\hline & TNF- $\alpha$ & 44.53 & 82.05 & $53.82^{*}$ & 12.80 \\
\hline & IL-I $\beta$ & 443.80 & II 57.00 & 863.90 & 238.49 \\
\hline & IL-6 & 16.89 & 33.00 & 23.36 & 6.30 \\
\hline & NO & 6.81 & 15.05 & 11.13 & 3.24 \\
\hline \multirow[t]{9}{*}{ HDL } & Alveolar congestion & 0 & 2 & $I^{*}$ & 0.52 \\
\hline & Alveolar hemorrhage & 0 & 2 & $0^{*}$ & 0.76 \\
\hline & Hyalen membrane & 0 & 0 & $0^{*}$ & 0.00 \\
\hline & Neutrophil infiltration & 0 & 1 & $0^{*}$ & 0.46 \\
\hline & NF-кB & I & 2 & $I^{*}$ & 0.46 \\
\hline & TNF- $\alpha$ & 43.55 & 61.76 & $48.66^{*}$ & 6.03 \\
\hline & IL-I $\beta$ & 407.70 & 991.40 & 670.59 & 220.86 \\
\hline & IL-6 & 15.74 & 27.25 & 20.92 & 3.94 \\
\hline & NO & 4.58 & 8.70 & 6.80 & 1.60 \\
\hline
\end{tabular}

"Median values. LDL: Low dose levosimendan; HDL: High dose levosimendan; NF-кB: Nuclear factor kappa B; TNF- $\alpha$ : Tumor necrosis factor alpha; IL6: Interleukin 6; NO: Nitric oxide; IL-IB: Interleukin I beta. 
Table 2. The statistically significant differences among all the groups described in the text with regard to alveolar congestion, alveolar hemorrhage, neutrophil infiltration, and NF- $\kappa B$ levels

\begin{tabular}{lccc}
\hline Variable & $\mathbf{X}^{2}$ & df & $\mathbf{p}$ \\
\hline Alveolar congestion & 17.965 & 3 & $<\mathbf{0 . 0 0 1}$ \\
Alveolar hemorrhage & 14.750 & 3 & $\mathbf{0 . 0 0 2}$ \\
Hyalene membrane & 3.000 & 3 & 0.392 \\
Neutrophil infiltration & 15.001 & 3 & $\mathbf{0 . 0 0 2}$ \\
NF-KB & 18.619 & 3 & $<\mathbf{0 . 0 0 1}$ \\
TNF- $\alpha$ & 11.994 & 3 & $\mathbf{0 . 0 0 7}$ \\
\hline
\end{tabular}

Kruskal-Wallis multiple variant analysis; $\mathrm{p}<0.05$ (df, degrees of freedom; $\mathrm{X}^{2}$, chisquare).

NF-KB: Nuclear factor kappa B; TNF- $\alpha$ : Tumor necrosis factor alpha.

amination revealed a difference among the groups with respect to alveolar congestion $\left(X^{2}=17.965 ; p<0.001\right)$, alveolar hemorrhage $\left(X^{2}=14.750 ; P=0.002\right)$, neutrophil infiltration $\left(X^{2}=15.00 I ; p=0.002\right)$, and NF-KB $\left(X^{2}=18.619 ; p<0.00 I\right)$. No statistically significant difference was determined among the groups with regard to hyaline membrane formation $\left(X^{2}=3.000 ; p=0.392\right)$ (Tables I, 2, and 3; Fig. 3).
A statistically significant difference was determined among the following groups with respect to alveolar congestion: control/sham $(Z=-3.340 ; p=0.00 I)$; control/LDL $(Z=-3.354$; $p=0.00 \mathrm{I})$, and control/YDL $(Z=-2.887 ; p=0.004)$. No difference was observed among the groups with regard to the reduction of alveolar congestion. In addition, a statistically significant difference was determined among the groups with regard to alveolar hemorrhage: control/sham ( $Z=-3.332$; $p=0.00 I)$ and control/LDL $(Z=-2.912 ; p=0.004)$. No difference was observed among the groups with respect to the reduction of alveolar hemorrhage.

A statistically significant difference was determined among the groups with respect to neutrophil infiltration: control/ sham $(Z=-3.359 ; p=0.00 I)$, sham/YDL $(Z=-2.646 ; p=0.008)$, and sham/LDL $(Z=-2.988 ; p=0.003)$. Neutrophil infiltration was higher in the sham group than in the other groups. From this, it was determined that LDL and HDL reduced neutrophil infiltration in the pulmonary tissue with contusion (Table 3).

\section{Immunohistochemical Evaluation}

NF- $\kappa B$ levels were different among all the groups: control/sham $(Z=-3.385 ; p=0.00 I)$, control/LDL $(Z=-I . I \mid 8 ; p=0.00 I)$, and

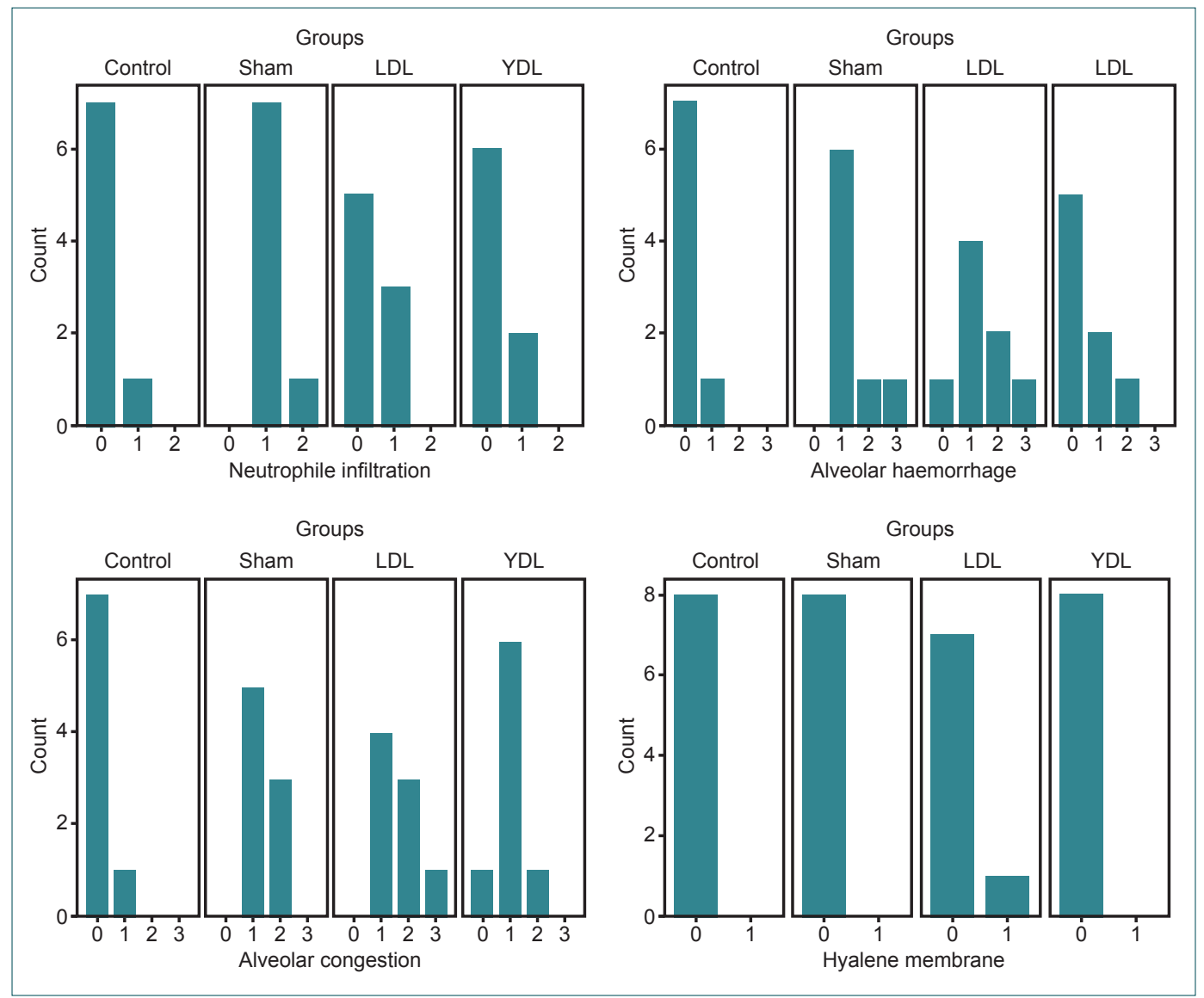

Figure 3. Variation of histopathological grades of each group. Each bar shows neutrophil infiltration, alveolar hemorrhage, alveolar congestion, and hyaline membrane values. 
Table 3. Low and high doses of levosimendan reduced neutrophil infiltration in the pulmonary contusion tissue

\begin{tabular}{|c|c|c|c|}
\hline Variable & Groups & $\mathbf{Z}$ & $\mathbf{p}$ \\
\hline Alveolar & Control/Sham & -3.340 & 0.001 \\
\hline \multirow[t]{5}{*}{ congestion } & Control/LDL & -3.354 & 0.001 \\
\hline & Control/HDL & -2.887 & 0.004 \\
\hline & Sham/LDL & -0.657 & $0.5 \mathrm{II}$ \\
\hline & Sham/HDL & -1.356 & 0.175 \\
\hline & LDL/HDL & -1.767 & 0.077 \\
\hline Alveolar & Control/Sham & -3.332 & 0.001 \\
\hline \multirow[t]{5}{*}{ hemorrhage } & Control/LDL & -2.912 & 0.004 \\
\hline & Control/HDL & -1.179 & 0.239 \\
\hline & Sham/LDL & -0.061 & 0.952 \\
\hline & Sham/HDL & -2.227 & 0.026 \\
\hline & LDL/HDL & -1.947 & 0.052 \\
\hline Neutrophil & Control/Sham & -3.359 & 0.001 \\
\hline \multirow[t]{5}{*}{ infiltration } & Control/LDL & -1.118 & 0.264 \\
\hline & Control/HDL & -0.620 & 0.535 \\
\hline & Sham/LDL & -2.646 & 0.008 \\
\hline & Sham/HDL & -2.988 & 0.003 \\
\hline & LDL/HDL & -.522 & 0.602 \\
\hline \multirow[t]{6}{*}{ NF-кB } & Control/Sham & -3.385 & 0.001 \\
\hline & Control/LDL & -3.354 & 0.001 \\
\hline & Control/HDL & -3.335 & 0.001 \\
\hline & Sham/LDL & -0.623 & 0.533 \\
\hline & Sham/HDL & $-|.65|$ & 0.099 \\
\hline & LDL/HDL & -1.108 & 0.268 \\
\hline \multirow[t]{6}{*}{ TNF- $\alpha$} & Control/Sham & $-2.94 I$ & 0.003 \\
\hline & Control/LDL & -1.787 & 0.074 \\
\hline & Control/HDL & -0.630 & 0.529 \\
\hline & Sham/LDL & -1.892 & 0.059 \\
\hline & Sham/HDL & -2.521 & 0.012 \\
\hline & LDL/HDL & -1.156 & 0.248 \\
\hline
\end{tabular}

Mann-Whitney $U$ test and Bonferroni multiple comparison test; $p<0.0083$. LDL: Low dose levosimendan; HDL: High dose levosimendan; NF-KB: Nuclear factor kappa B; TNF- $\alpha$ : Tumor necrosis factor alpha.

control/YDL ( $Z=-3.335 ; p=0.00 I)$ (Table 3). Although NF-KB levels were not statistically significantly different among the groups, the levels were numerically lower in the LDL and HDL groups than in the control and sham groups.

\section{Biochemical Evaluation}

Statistical analysis of the results of the biochemical evaluation revealed a difference among the groups with respect to the serum levels of IL-I $\beta(F=16.719 ; p<0.00 I)$, IL-6 $(F=4.955$; $\mathrm{p}=0.007)$, NO $(\mathrm{F}=4.855 ; \mathrm{p}=0.008)$, and TNF- $\alpha\left(\mathrm{X}^{2}=1 \mathrm{I} .994\right.$; $\mathrm{p}=0.007)($ Table 4, 5, Fig. 4).
Table 4. Descriptive table of the mean values of IL-I $\beta$, IL-6, and NO and median values of TNF- $\alpha$ levels

\begin{tabular}{lccc}
\hline Variable & F & df & p \\
\hline IL-IB & 16.719 & 3 & $<0.00$ I \\
IL-6 & 4.955 & 3 & $\mathbf{0 . 0 0 7}$ \\
NO & 4.855 & 3 & $\mathbf{0 . 0 0 8}$
\end{tabular}

$\mathrm{P}<0.05$. SD: Standard deviation. IL-IB: Interleukin I beta; IL6: Interleukin 6; NO: Nitric oxide.

A statistically significant difference was determined among the groups regarding serum IL-I $\beta$ levels: control/sham $(p<0.00 \mathrm{I})$, control/LDL $(p=0.022)$, sham/LDL $(p=0.005)$, sham/LDL $(p<0.00 \mathrm{I})$, and LDL/YDL $(p=0.005)$. Reduced serum IL-I $\beta$ levels were observed in the LDL and HDL groups.

A statistically significant difference was determined among the groups with regard to serum IL-6 levels: sham/LDL $(p=0.028)$ and sham/YDL $(p=0.008)$. The use of HDL significantly reduced serum IL-6 levels.

A statistically significant difference was determined with respect to serum $\mathrm{NO}$ levels only between the sham/YDL $(p=0.005)$ and LDL/YDL $(p=0.006)$ groups (Table 5$). \mathrm{HDL}$ significantly reduced serum $\mathrm{NO}$ levels.

Serum TNF- $\alpha$ levels were different only between the control/ sham $(Z=-2.941 ; p=0.003)$ groups (Table 3$)$.

\section{DISCUSSION}

Previous studies demonstrated that the effect of chest trauma increased with the occurrence of respiratory complications, such as ALI/ARDS, associated with the trauma severity. ${ }^{[6-18]}$ In patients with multiple trauma, if PC occurs, the mortality rate increases from $27 \%$ to $56 \%$. In addition, animal experimental studies revealed that after trauma, there are severe local and systemic inflammatory changes, which potentially trigger septic complications, and the organ failure that first develops in this table is respiratory failure. ${ }^{[19]}$ In the current study, an increase in the systemic inflammatory response and development of severe bradycardia and hypotension, as a clinical reflection, were observed more in the trauma groups than in the control group. In the LDL and HDL groups, where doses administered were similar to those in used in the clinical practice, the mean arterial pressure significantly reduced. In the clinical practice, levosimendan is administered for hypotension, and so, to observe the effect on hypotension in the current study, the following two different doses were administered: $5 \mu \mathrm{g} / \mathrm{kg}$ loading dose for $10 \mathrm{~min}$, followed by $0.05 \mu \mathrm{g} / \mathrm{kg} / \mathrm{min}$ intravenous infusion, and $10 \mu \mathrm{g} / \mathrm{kg}$ loading dose for $10 \mathrm{~min}$, followed by $0.1 \mu \mathrm{g} / \mathrm{kg} / \mathrm{min}$ intravenous infusion. No statistically significant differences were observed with regard to the mean arterial blood pressure or heart rate in the LDL and HDL groups. 
Table 5. The variations in mean values of IL-I $\beta$, IL-6, and NO were statistically significant among all groups

\begin{tabular}{|c|c|c|c|c|}
\hline Variable & Groups & Mean difference (I-J) & Standard Error & $\mathbf{p}$ \\
\hline \multirow[t]{6}{*}{ IL-I $\beta$} & Control/Sham & -1004.58 & 147.25 & $<0.001$ \\
\hline & Control/LDL & -455.88 & 147.25 & 0.022 \\
\hline & Control/HDL & -262.56 & 147.25 & 0.302 \\
\hline & Sham/LDL & 548.70 & 147.25 & 0.005 \\
\hline & Sham/HDL & 742.01 & 147.25 & $<0.001$ \\
\hline & LDL/HDL & 193.31 & 147.25 & 0.563 \\
\hline \multirow[t]{6}{*}{ IL-6 } & Control/Sham & -7.34 & 4.48 & 0.376 \\
\hline & Control/LDL & 6.04 & 4.48 & 0.542 \\
\hline & Control/HDL & 8.49 & 4.48 & 0.254 \\
\hline & Sham/LDL & 13.38 & 4.48 & 0.028 \\
\hline & Sham/HDL & 15.82 & 4.48 & 0.008 \\
\hline & LDL/HDL & 2.45 & 4.48 & 0.947 \\
\hline \multirow[t]{6}{*}{ NO } & Control/Sham & -1.37 & 1.20 & 0.669 \\
\hline & Control/LDL & -2.41 & 1.20 & 0.207 \\
\hline & Control/HDL & 1.91 & 1.20 & 0.399 \\
\hline & Sham/LDL & -1.05 & 1.20 & 0.818 \\
\hline & Sham/HDL & 3.28 & 1.20 & 0.050 \\
\hline & LDL/HDL & 4.33 & 1.20 & 0.006 \\
\hline
\end{tabular}

One-Way ANOVA test, $\mathrm{p}<0.05$. df: Degrees of freedom; F: F test. LDL: Low dose levosimendan; HDL: High dose levosimendan; IL6: Interleukin 6; NO: Nitric oxide; IL-IB: Interleukin I beta.

PC, which is widely observed after blunt thorax trauma, is an injury that may result in morbidity and mortality. ${ }^{[20]}$ In the current study, because the results of the histopathological examination of pulmonary tissues obtained $6 \mathrm{~h}$ after the formation of blunt thorax trauma, which included alveolar hemorrhage, alveolar edema, and neutrophil infiltration, were similar to the those of the trauma model described by Raghavendran et al., the efficacy of the current study model was confirmed. [15] According to these results, PC model was successfully established in the rats. After analyzing the results obtained from the histopathological examination in this study, although a statistical difference was not observed, when the median values were examined, the high dose of levosimendan was considered to reduce alveolar hemorrhage that developed after trauma; however, when a low dose was administered, no effect on alveolar hemorrhage was observed. In addition, at both low and high doses, levosimendan reduced neutrophil infiltration in damaged pulmonary tissues. However, levosimendan did not have any effect on reducing alveolar congestion. Based on these findings, it was considered that levosimendan did not reduce alveolar congestion but was effective in reducing inflammatory cell infiltration and alveolar hemorrhage in PCs that developed after blunt thoracic trauma.

In experimental studies of pulmonary damage, an intense inflammatory response developed in damaged tissues, and the chemokines that were particularly expressed by alveolar macrophages activated neutrophils. ${ }^{[2]}$ It has been proposed that reactive oxygen radicals, tissue fragmenting proteinases, and cationic polypeptides in proinflammatory cytokines (e.g., ILI $\beta$, IL-6, TNF- $\alpha$, and NO), expressed by active neutrophils, are a risk factor for increase in tissue damage and the development of ARDS. ${ }^{[22]}$ NF- $\kappa B$, a proinflammatory factor, has a regulatory role in the emergence of several of the abovementioned mediators. ${ }^{[7]}$ In an experimental animal model study by Perl et al.," ${ }^{[23]}$ the inflammatory effects of PC were examined in mononuclear cells in the peripheral blood, peritoneal macrophages, splenocytes, and splenic macrophages and on plasma TNF- $\alpha$ and IL- 6 levels. At the end of the study, it was reported that $P C$ caused severe immune function impairment systemically and in different compartments.

In the current study, PC induced in the rats increased NF$\kappa \mathrm{B}$ activation in the pulmonary tissue, and levosimendan did not reduce this activation. Although statistical analysis did not reveal any difference between the groups, the TNF- $\alpha$ formation could have been suppressed in the serum samples of the LDL and HDL groups. While the serum IL-I $\beta$ level reduced after administration of low and high doses of levosimendan, serum IL-6 and NO levels reduced with high doses only. In the current study, serum levels of the proinflammatory cytokines IL-I $\beta$ and TNF- $\alpha$ significantly increased in 

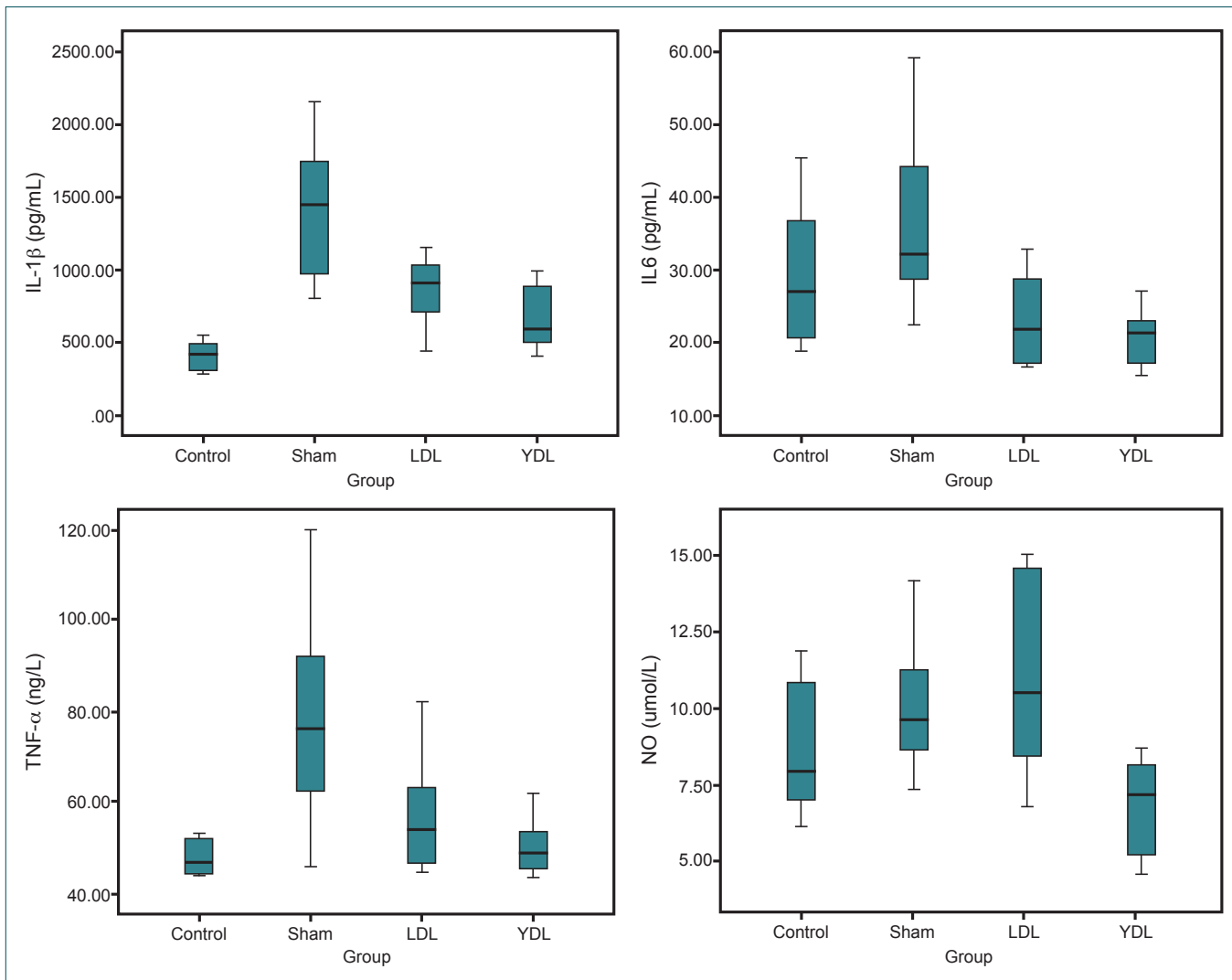

Figure 4. Mean values of IL-1 $1 \beta$, IL-6, and NO and median value of TNF- $\alpha$ of all groups compared with the control group. Each error bar shows the minimum and maximum biochemical values.

the sham group compared with those in the control group. These results suggested that proinflammatory cytokine formation after blunt thoracic trauma was suppressed by levosimendan.

\section{Limitations}

This study had some limitations. First, this study evaluated the effects of levosimendan on the systemic inflammatory response, but for technical and financial reasons, advanced biochemical and histopathological examination of inflammatory response inhibitors, which are developed in damaged pulmonary tissues, were not performed. Second, the low and high doses of levosimendan used in this study were within the dose ranges recommended in the guidelines for the diagnosis and treatment of acute heart failure; therefore, it would be appropriate to conduct further studies of higher doses and assess the long-term effects of such doses. If a more significant increase is observed in the antiinflammatory properties of HDL compared LDL, the selection of the dose to be used should be patient-based in the clinical use. Therefore, considering the effects of the local and systemic response on mortality following PC development after thorax trauma, further studies over a longer term with higher doses would be useful with respect to clinical safety. Third, owing to technical and financial restrictions, arterial blood gas analysis was not performed, and saturation was not monitored.

\section{Conclusion}

In conclusion, the study results revealed that in a rat model of PC, the experimental agent levosimendan could reduce neutrophil infiltration to damaged pulmonary tissues and decrease the systemic release of some cytokines (such as IL$\mathrm{I} \beta$, IL-6, and NO), thus partially reducing and/or correcting pulmonary damage. Therefore, levosimendan is considered to reduce systemic inflammatory responses that occur after trauma and is clinically beneficial for patients with PC.

\section{Funding}

This study was supported by Kırıkkale University Scientific Research Council (2014/84).

Conflict of interest: None declared.

\section{REFERENCES}

1. Raghavendran K, Davidson BA, Woytash JA, Helinski JD, Marschke CJ, Manderscheid PA, et al. The evolution of isolated bilateral lung contusion from blunt chest trauma in rats: cellular and cytokine responses. Shock 2005;24:132-8.

2. Oppenheimer L, Craven KD, Forkert L, Wood LD. Pathophysiology of pulmonary contusion in dogs. J Appl Physiol Respir Environ Exerc Physiol 1979;47:718-28.

3. Hoth JJ, Martin RS, Yoza BK, Wells JD, Meredith JW, McCall CE. Pulmonary contusion primes systemic innate immunity responses. J Trauma 2009;67:14-22. 
4. Lenz A, Franklin GA, Cheadle WG. Systemic inflammation after trauma. Injury 2007;38:1336-45.

5. Fang DQ, Yu T, Wan L. Effect of nuclear factor-kappa B decoy oligodeoxynucleotides on IL-10, IL-13 and nuclear factor-kappa B protein expressions in rabbits with severe lung contusion. Nan Fang Yi Ke Da Xue Xue Bao 2010;30:2284-7.

6. Shapiro H, Kagan I, Shalita-Chesner M, Singer J, Singer P. Inhaled aerosolized insulin: a "topical" anti-inflammatory treatment for acute lung injury and respiratory distress syndrome? Inflammation 2010;33:315-9.

7. Fudala R, Allen TC, Krupa A, Cagle PT, Nash S, Gryczynski Z, et al. Increased levels of nuclear factor $\kappa \mathrm{B}$ and Fos-related antigen 1 in lung tissues from patients with acute respiratory distress syndrome. Arch Pathol Lab Med 2011;135:647-54.

8. Erickson SE, Martin GS, Davis JL, Matthay MA, Eisner MD, Recent trends in acute lung injury mortality: 1996-2005. Crit Care Med 2009;37:1574-9.

9. Cohn SM, Dubose JJ. Pulmonary contusion: an update on recent advances in clinical management. World J Surg 2010;34:1959-70.

10. Moreno N, Tavares-Silva M, Lourenço AP, Oliveira-Pinto J, HenriquesCoelho T, Leite-Moreira AF. Levosimendan: The current situation and new prospects. Rev Port Cardiol 2014;33:795-800.

11. Karakus E, Halici Z, Albayrak A, Bayir Y, Aydin A, Unal D, et al. Beneficial pharmacological effects of levosimendan on antioxidant status of acute inflammation induced in paw of rat: involvement in inflammatory mediators. Basic Clin Pharmacol Toxicol 2013;112:156-63.

12. Yasa H, Yakut N, Emrecan B, Ergunes K, Ortac R, Karahan N, et al. Protective effects of levosimendan and iloprost on lung injury induced by limb ischemia-reperfusion: a rabbit model. J Surg Res 2008;147:138-42.

13. Oldner A, Konrad D, Weitzberg E, Rudehill A, Rossi P, Wanecek M. Effects of levosimendan, a novel inotropic calcium-sensitizing drug, in experimental septic shock. Crit Care Med 2001;29:2185-93.
14. Dubin A, Maskin B, Murias G, Pozo MO, Sottile JP, Barán M, et al. Effects of levosimendan in normodynamic endotoxaemia: a controlled experimental study. Resuscitation 2006;69:277-86.

15. Raghavendran K, Davidson BA, Helinski JD, Marschke CJ, Manderscheid P, Woytash JA, et al. A rat model for isolated bilateral lung contusion from blunt chest trauma. Anesth Analg 2005;101:1482-9.

16. Edens JW, Chung KK, Pamplin JC, Allan PF, Jones JA, King BT, et al. Predictors of early acute lung injury at a combat support hospital: a prospective observational study. J Trauma 2010;69 Suppl 1:81-6.

17. Maier M, Geiger EV, Wutzler S, Lehnert M, Wiercinski A, Buurman WA, et al. Role of lung contusions on posttraumatic inflammatory response and organ dysfunction in traumatized patients. Eur J Trauma Emerg Surg 2009;35:463-9.

18. Miller PR, Croce MA, Bee TK, Qaisi WG, Smith CP, Collins GL, et al. ARDS after pulmonary contusion: accurate measurement of contusion volume identifies high-risk patients. J Trauma 2001;51:223-30.

19. Knöferl MW, Liener UC, Seitz DH, Perl M, Brückner UB, Kinzl L, et al. Cardiopulmonary, histological, and inflammatory alterations after lung contusion in a novel mouse model of blunt chest trauma. Shock 2003;19:519-25.

20. Bamvita JM, Bergeron E, Lavoie A, Ratte S, Clas D. The impact of premorbid conditions on temporal pattern and location of adult blunt trauma hospital deaths. J Trauma 2007;63:135-41.

21. Azoulay E, Darmon M, Delclaux C, Fieux F, Bornstain C, Moreau D, et al. Deterioration of previous acute lung injury during neutropenia recovery. Crit Care Med 2002;30:781-6.

22. Grommes J, Soehnlein O. Contribution of neutrophils to acute lung injury. Mol Med 2011;17:293-307.

23. Perl M, Gebhard F, Brückner UB, Ayala A, Braumüller S, Büttner C, et al. Pulmonary contusion causes impairment of macrophage and lymphocyte immune functions and increases mortality associated with a subsequent septic challenge. Crit Care Med 2005;33:1351-8.

\section{DENEYSEL ÇALIŞMA - ÖZET}

\section{Deneysel künt toraks travma modelinde levosimendanın sistemik antienflamatuvar etkilerinin araştırılması}

\section{Dr. Gökay Ateş, ${ }^{1}$ Dr. Ferda Yaman, ${ }^{1}$ Dr. Bülent Bakar, ${ }^{2}$ Dr. Üçler Kısa, ${ }^{3}$ Dr. Pınar Atasoy, ${ }^{4}$ Dr. Ünase Büyükkoçak ${ }^{1}$}

${ }^{1}$ Kırıkkale Üniversitesi Tıp Fakültesi, Anesteziyoloji ve Reanimasyon Anabilim Dalı, Kırıkkale

${ }^{2}$ Kırıkkale Üniversitesi Tıp Fakültesi, Beyin ve Sinir Cerrahi Anabilim Dalı, Kırıkkale

${ }^{3}$ Kırıkkale Üniversitesi Tıp Fakültesi, Tıbbi Biyokimya Anabilim Dalı, Kırıkkale

${ }^{4}$ Kırıkkale Üniversitesi Tıp Fakültesi, Patoloji Anabilim Dalı, Kırıkkale

AMAÇ: Künt toraks travması sıklılıla pulmoner kontüzyona yol açar, lokal ve sistemik enflamatuvar durumlardan kaynaklanan yüksek morbidite ve mortalite riski taşıyan akut solunum sıkıntısı sendromunun gelişmesine neden olur. Bu çalışmanın amacı sıçanlarda künt göğüs travma modelinde levosimendanın lokal ve sistemik antienflamatuvar etkilerini araştırmaktır.

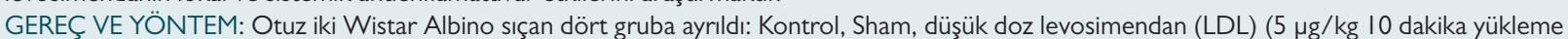
doz, $0.05 \mu \mathrm{g} / \mathrm{kg} / \mathrm{dk}$ intravenöz infüzyon) ve yüksek doz levosimendan (YDL) (10 $\mu \mathrm{g} / \mathrm{kg} 10$ dakika yükleme doz, $0.1 \mu \mathrm{g} / \mathrm{kg} / \mathrm{dk}$ intravenöz infüzyon) grubu olarak belirlendi. Künt göğüs travmasından altı saat sonra histopatolojik ve immünohistokimyasal değerlendirme için kontüze pulmoner dokular çıkarılmıştır ve serumda TNF- $\alpha$, IL-I $\beta$, IL-6, NO düzeyleri biyokimyasal olarak değerlendirildi.

BULGULAR: Düşük doz levosimendan ve YDL grubunda ortalama arter basınçları deney boyunca düşük seyretti ve aralarında istatistiksel olarak anlamlı fark saptanmadı. Levosimendanın travma sonrası oluşan alveolar konjesyonu ve hemorajiyi azaltmadığı saptandı. Ancak levosimendanın düşük ve yüksek dozlarda hasarlı akciğer dokusuna nötrofil infiltrasyonunu azalttığı tespit edildi. PC oluşturulan sıçanlarda akciğer dokusunda NF$\kappa B^{\prime}$ nin aktivasyonunun arttığı ancak levosimendanın bu aktivasyonu azaltamadığı gözlendi. Öte yandan levosimendanın düşük ve yüksek dozlarda verildiğinde serum IL-I $\beta$ seviyesini azalttı̆̆ı; yüksek dozlarda uygulandığında da IL-6 ve NO oranlarını azalttı̆ı̆ tespit edildi. Ancak serum TNF- $\alpha$ seviyelerini azaltamadığı saptandı.

TARTIŞMA: Sonuç olarak levosimendan isimli deneysel ajanın sıçanlarda oluşturulan pulmoner kontüzyon modelinde hasarlı akciğer dokusuna nötrofil hücre infiltrasyonunu ve bunlardan salınacak bazı sitokinlerin (IL-I $\beta$, IL-6, NO) sistemik salınımını azaltabileceği ve böylece pulmoner hasarı kısmen azaltabileceği ve/ veya düzeltebileceği; travma sonrası ortaya çıkan sistemik enflamatuvar yanıtı da azaltabileceği düşünülmüştür. Anahtar sözcükler: Akciğer kontüzyonu; B, enflamasyon, künt göğüs travması, levosimendan; nükleer faktör $\kappa$. 